\title{
Phylogeographic patterns of Calophyllum Braziliense Camb. (Calophyllaceae) based on the psbA-trnH cpDNA locus
}

\author{
Fabiano Salgueiro ${ }^{1 *}$, Jordana Neri ${ }^{2}$, Marcio Alves-Ferreira ${ }^{3}$, Fabio Scarano ${ }^{4}$ \\ From IUFRO Tree Biotechnology Conference 2011: From Genomes to Integration and Delivery \\ Arraial d'Ajuda, Bahia, Brazil. 26 June - 2 July 2011
}

\section{Background}

Past climate changes have severely influenced the current distribution of species and their genetic diversity. Phylogeography is the study of the principles and processes governing the geographic distributions of genealogical lineages [1]. South America has the world's largest area of swamps, floodplains and wetlands in general [2]. Brazil's major wetlands cover $2 \%$ of the country's huge territory [3]. However, from a plant ecology standpoint, Brazilian freshwater wetlands are largely unknown and the scarce data available refer mostly to flooded forests of the Amazon [4]. Calophyllum Braziliense Camb. (Calophyllaceae), also know as guanandi, jacareúba or landim, is a canopy tree species typical of waterlogged areas from South and Central America. This species occurs in the humid tropical forests of Central America, Amazon Forests, Atlantic Forest (including restingas); and in the riverines forests of the Cerrado biome (brazilian savannah) [5,6]. However, unlike other species typical of flooded areas, C. Braziliense shows none of the morphological features common to flood-adapted plants. Calophyllum Braziliense is a hermaphroditic tree pollinated by bees. Its seeds are animal (mainly by bats) or water dispersed. The timber has excellent characteristics and is widely used. Calophyllum. Braziliense is also used in vegetation restoration programs and its leaves extract presents antiinflammatory activity [7]. This study examines the phylogeographic patterns of C. Braziliense based on the cpDNA intergenic region $p s b \mathrm{~A}-t r n \mathrm{H}$.

\footnotetext{
* Correspondence: fabiano.salgueiro@gmail.com

'Departamento de Botânica, Universidade Federal do Estado do Rio de Janeiro, Rio de Janeiro, Brazil

Full list of author information is available at the end of the article
}

\section{Methods}

Twenty four populations of C. Braziliense were sampled from Costa Rica $\left(10^{\circ} 12^{\prime} \mathrm{N}, 83^{\circ} 47^{\prime} \mathrm{W}\right)$ to the Paraná

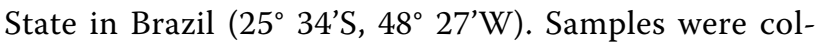
lected from about 5-10 adult trees in each population, totaling 192 individuals. Total DNA was extracted from leaves or cambium using the CTAB procedure described by Doyle \& Doyle [8]. After a screening for cpDNA amplification and polymorphism in C. Braziliense, the $p s b \mathrm{~A}-t r n \mathrm{H}$ intergenic regions was selected [9]. Sequences were aligned using CLUSTAL-W implemented in the MEGA 4 software. The cpDNA haplotypes were defined by analyzing the sequences with DNASP 4.01. The genetic diversity indexes were estimated in ARLEQUIN 3.01. The phylogenetic relationships among the haplotypes were estimated using the median-joining algorithm implemented in NETWORK 4.1. An analysis of molecular variance (AMOVA) was performed in ARLEQUIN. A spatial analysis of molecular variance (SAMOVA) was conduced using the SAMOVA 1.0 software. To evaluate the hypothesis of population expansion, neutrality tests were computed in DNASP and ARLEQUIN.

\section{Results}

A total of 263 aligned positions were obtained for the $p s b \mathrm{~A}-t r n \mathrm{H}$ locus. Twenty-eight variable characters were analyzed resulting in seven cpDNA haplotypes (Figure $1)$. The haplotype diversity $(h)$ for each population ranged from 0.0 to 0.533 and the nucleotide diversity $(\pi)$ from 0.0 to 0.01882 . Similar levels of genetic diversity were observed for other tropical species [10,11]. Most of the Atlantic rain forest populations (13/14) are monomorphic and present the same haplotype (H1). Generally, the remaining populations present different private 


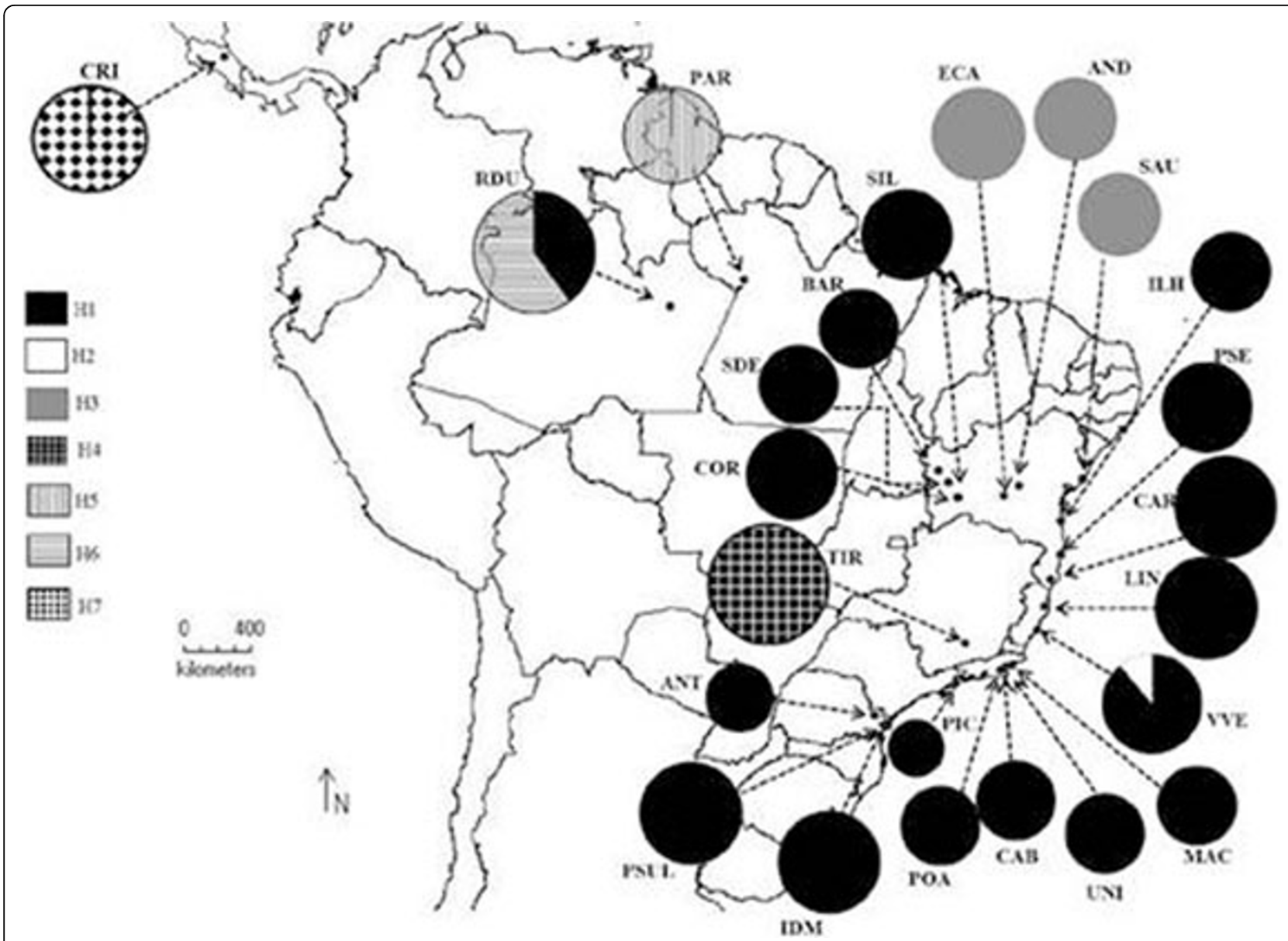

Figure 1 Map showing the geographic distribution of the cpDNA haplotypes in the Calophyllum Braziliense populations.

haplotypes. Spatial analysis of molecular variance (SAMOVA) identified seven phylogroups $(k=7, F c t=$ 0,926), one consisting of 13 monomorphic populations from the Brazilian Atlantic rain forest and more three populations from de Cerrado biome. Most of the others populations constitute different phylogroups. Neutrality tests suggest expansion for the Atlantic rain forest populations. The AMOVA analysis reveals that most of the variation was found between populations $(0.8788$, $p<0.00005)$. A great genetic distance was observed between Central America (Costa Rica) and the others populations, even from the Brazilian Amazon forest. Similar results were observed when Swietenia macrophylla (mahogany) populations from Central and South America were compared [10].

\section{Conclusions}

The genetic data obtained here for C. Braziliense based on chloroplast DNA diversity indicate a recent expansion for the Atlantic rain forest populations. Our results suggest that the Northeast of Brazil maintained large populations during the last glacial period and that the Southeast and South populations may have undergone a pronounced retraction process, followed by a recolonization process with a strong founder effect. Thus, the recolonization of the South and Southeast region of the Atlantic rain forest probably occurred from these more stable areas in the Northeast.

\section{Acknowledgements}

This work was funded by FAPERJ - Fundação Carlos Chagas Filho de Amparo à Pesquisa do Estado do Rio de Janeiro. Jordana Neri received a fellowships from CAPES - Coordenação de Aperfeiçoamento de Pessoal de Nível Superior.

\section{Author details}

'Departamento de Botânica, Universidade Federal do Estado do Rio de Janeiro, Rio de Janeiro, Brazil. ²Programa de Pós-Graduação em Botânica, Instituto de Pesquisas Jardim Botânico do Rio de Janeiro, Rio de Janeiro, Brazil. ${ }^{3}$ Departamento de Genética, Universidade Federal do Rio de Janeiro, Rio de Janeiro, Brazil. ${ }^{4}$ Departamento de Ecologia, Universidade Federal do Rio de Janeiro, Rio de Janeiro, Brazil.

Published: 13 September 2011 


\section{References}

1. Avise J: Phylogeography: the history and formation of species. Harvard University Press; 2000.

2. Aselmann I, Crutzen P: Global distribution of natural freshwater wetlands and rice paddies, their net primary productivity, seasonality and possible methane emissions. J Atmos Chem 1989, 8:307-358.

3. World Conservation Monitoring Centre. Chapman \& Hall, London; 1992 594.

4. Scarano F, Ribeiro K, Moraes L, Lima H: Plant establishment on flooded and unflooded patches of a freshwater swamp forest in Southeastern Brazil. J Trop Ecol 1997, 14:793-803.

5. Reitz R, Klein R, Reis A: Projeto madeira de Santa Catarina. Sellowia; 1978:28-30:218-224.

6. Oliveira-Filho A, Ratter J: A study of the origin of central Brazilian forests by the analysis of plant species distribution patterns. Edinb J Bot 1995, 52(2):141-194.

7. Carvalho P: Espécies florestais Brazileiras recomendações silviculturais, potencialidades e uso da madeira. Colombo, Embrapa Florestas 1994, 640

8. Doyle J, Doyle J: Isolation of plant DNA from fresh tissue. Focus 1987, 12:13-15.

9. Hamilton M: Four primers pairs for the amplification of chloroplast intergenic regions with intraspecific variation. Mol Ecol 1999, 8:521-523.

10. Lemes M, Dick C, Navarro C, Lowe A, Cavers S, Gribel R: Chloroplast DNA microsatellites reveal contrasting phylogeographic structure in mahogany (Swietenia macrophylla King. Meliaceae) from Amazonia and Central America. Trop Plant Biol 2010, 3:40-49.

11. Novaes R, Lemos-Filho J, Ribeiro R, Lovato M: Phylogeography of Plathymenia reticulate (Leguminosae) reveals patterns of recent range expansion towards northeastern Brazil and southern Cerrados in Eastern Tropical South America. Mol Ecol 2010, 19:985-998.

doi:10.1186/1753-6561-5-S7-P17

Cite this article as: Salgueiro et al:: Phylogeographic patterns of Calophyllum Braziliense Camb. (Calophyllaceae) based on the psbA-trnH cpDNA locus. BMC Proceedings 2011 5(Suppl 7):P17.

\section{Submit your next manuscript to BioMed Central} and take full advantage of:

- Convenient online submission

- Thorough peer review

- No space constraints or color figure charges

- Immediate publication on acceptance

- Inclusion in PubMed, CAS, Scopus and Google Scholar

- Research which is freely available for redistribution

Submit your manuscript at www.biomedcentral.com/submit
Biomed Central 